\title{
Possibilities to Develop Local Tourism Potential by European Regional Development Fund (The CASE OF BuRGas MuNICIPALITY)
}

\section{Abstract:}

This paper provides an overview of the funding opportunities for projects in Bulgarian municipalities from the European Regional Development Fund under Operational programme "Regional Development" 2007-2013 and Operational programme „Regions in Growth" 20142020 in the context of the development of the local tourism potential. Besides being presented opportunities for supporting the development of local tourism potential by European Regional Development Fund at national level, this work is focused on the possibilities to develop local tourism potential by EU funding following the example of the Burgas Municipality.

A review of the implemented projects, funed under operational programmes, of the Burgas Municipality during the programming period 20072013 has been carried out. The European Regional Development Fund co-funded projects concerning the development of tourism are classified into several groups. Opportunities for EU funding projects in the current programming period 20142020are revealed in the context of the development of alternative forms of tourism.

Besides the opportunities for supporting the development of local potential by EU Funds at national level, this paper introduces also the possibilities to develop local tourism potential by EU funding following the example of the Burgas Municipality.

\section{Keywords:}

regional development, operational programme, Eu funding, Bulgaria

\section{Author s data:}

${ }^{1}$ Hristova Sevdalina, Assistant Prof. PhD, University of Economics - Varna, Faculty of Economics, Economics and Managment of Construction Department; 77, Knyaz Boris I Bvd., 9002 Varna, Bulgaria; s.hristova@ue-varna.bg 


\section{Introduction}

Tourism is considered one of the important sectors of the Bulgarian economy. The specific resources of the Bulgarian regions and municipalities, in particular, favour the development of sustainable forms of tourism - natural, cultural, environmental, etc. In recent years, tourism has established itself as a thriving business area, which has a significant share in the gross national product and generates employment . At the same time, tourism is an activity that can provide a good foundation for the development of innovations, thus contributing to the positive image of the regions as well as their economic and social development. Undoubtedly, in many Bulgarian municipalities there is considerable local potential, such as immovable cultural assets, natural resources and landmarks, suitable climatic conditions, landscapes. This potential remains underutilized for the development of tourist activities.

The available local tourism potential can be developed by the municipalities through various activities involving conservation and restoration of immovable cultural assets, introduction of modern forms of showcasing immovable cultural assets, renovation of museums, development of tourism infrastructure, suitable for rural, spa, adventure, sports and other types of tourism. All of that requires significant financial resources.

European funds and in particular the European Regional Development Fund (ERDF), are one of the possibilities to fund projects for the development of local tourism potential. For the programming period 2014-2020, Bulgarian municipalities are one of the main beneficiaries in four of the seven operational programmes. Municipalities will have access to ERDF for the development of local tourism potential through the Operational Programme "Regions in growth" 2014-2020.
Burgas municipality is one of the Bulgarian municipalities that actively benefit from EU funds to develop local tourism potential. In the programming period 2017-2013 it has implemented several successful projects that can be used as good practice.

In light of the aforementioned, the aim of the author of this work is based on research practice of Burgas Municipality to outline the opportunities and to derive some recommendations to the Bulgarian municipalities for more efficient development of local tourism potential through the implementation of projects funded by the ERDF under the Operational Programme "Regions in growth" 2014-2020.

\section{Supporting the development of local tourism potential in the programming period 2007-2013}

Bulgaria, as a full member of the Community, has access to the financial instruments of the European Union for the implementation of the Cohesion Policy and the Common Agricultural Policy. These are the European Regional Development Fund, the European Social Fund, the Cohesion Fund, the European Agricultural Fund for Rural Development and the European Fisheries Fund. Significant financial resources have been allocated for Bulgaria for the programming period 2007-2013. The financial framework amounts to just over 9 billion euros - 6,674 billion euros from the Structural (European Regional Development Fund and European Social Fund) and the Cohesion Funds, and 2,682 billion euros from the European Agricultural Fund for Rural Development and the European Fisheries Fund.

All six regions of Bulgaria corresponding to level II of the Nomenclature of Units for Territorial Statistics (NUTS II) are eligible for funding from the Structural Funds under the Convergence objective. Operational Programme Regional Development 
[OPRD), as one of the seven operational programs operating during the period 2007-2013, contributes to the implementation of the Cohesion Policy and is carried out with the assistance of the European Regional Development Fund. It is the only operational program for the six planning regions and is complemented by interventions within the National Strategic Plan for Rural Development.

Operational Programme Regional Development 2007-2013 aims to improve the socio-economic conditions in the 6 planning regions, i.e. to overcome their lagging behind the EU regions, on the one hand, and to reduce the interregional disparities in Bulgaria, on the other hand. [1]

For this purpose, the Operational Programme provides for a wide range of measures, from infrastructure to cultural heritage protection, taking into account both the general trends and the specifics of the different municipalities and settlements. Support is provided both for projects of large urban centers with high potential for economic growth and social inclusion, and for their neighbouring and peripheral areas, which at that point lag behind the overall development of the region. An important role plays the cooperation between the municipalities, which may ensure integrated and sustainable development accordingly.

Priority axis 3 of OPRD - Sustainable Tourism Development is in line with the Community Strategic Guidelines on Cohesion, where tourism is considered to be one of the measures to promote economic growth, and the preservation of historical and cultural heritage - as a potential for tourism development. The strategic Guidelines also emphasize the role of tourism in the development of rural areas mostly and the need for an integrated approach to quality, focusing on consumer satisfaction and based on the economic, social and environmental dimensions of the sustainable development.
The specific objective of the priority is to increase the potential for regional tourism development and marketing of sustainable and diversified, region-specific tourist products with high added value and increasing the sector's contribution to the sustainable regional development.

The financial resources to this priority amount to BGN 387437451 , of which BGN 329321834 are EU funding from the European Regional Development Fund. The total amount represents $12.37 \%$ of the entire programme.

Priority activities are concentrated in three operations:

- $\quad$ Operation 3.1 Enhancement of Tourism Attractions and Related Infrastructure. The objective of this operation is to develop integrated and distinctive tourism products based on competitive and marketable attractions that contribute to diversification and territorial spread of tourism.

- $\quad$ Operation 3.2 Regional Tourism Product Development and Marketing of Destinations. The objective of this operation is to increase the number of visitors and visitor days, to improve seasonal and territorial distribution of tourism development in different regions and areas based on integrated destination management and marketing and to use different tools, techniques and systems ensuring effective tourism information and marketing.

- $\quad$ Operation 3.3 National Tourist Marketing. The objective of this operation is to enhance the effectiveness and impacts of national marketing efforts and related activities, market intelligence and transparency to facilitate diversification of tourist products and markets and sustainable tourism development. Specific beneficiary of this operation is State Tourism Agency.

The data published in Unified Management Information system for management and 
monitoring of the EU structural instruments in Bulgaria can be used as an indication for the implementation of Priority Axis 3 Sustainable Tourism Development of OPRD 2007-2013 (see Tab. 1). Over 130 contracts have been concluded for the provision of grants to the total value of BGN 288297 459 or $74,41 \%$ of the budget under the Axis, of which BGN 200188688 have been actually paid as of the beginning of December 2014. The absorption rate is about $51 \%$.

Although the Ministry of Culture and the Ministry of Economy and Energy are the specific beneficiary of a significant part of the projects funded under this priority axis, more than 60 municipalities have successfully developed and implemented projects resulting in stimulating the development of sustainable forms of tourism and the promotion of cultural and natural values.

Under operation 3.1. supported objects are in the territory of the country. Some emblematic landmarks, including real cultural values of national and global significance, are supported. Supported project activities are:
- Development of nature, cultural and historic attractions;

- Development of tourism related infrastructure when and if needed for the use of attractions, incl. facilities and amenities for disabled and elderly visitors;

- Reconstruction and renovation/upgrading of publicly owned mountain chalets complementing tourism product development in remote areas, shelters and safety facilities;

- Complementary small scale technical infrastructure in the area of the attractions when and if needed for the use of attractions, such as access roads, utilities, amenities serving tourist attractions and visitor needs required to ensure the integrated development of tourism products;

- Complementary training of staff required for the operation of supported attractions and facilities;

- Complementary small scale noninfrastructural activities, explicitly related to the supported attractions.

\begin{tabular}{|c|c|c|c|c|c|}
\hline \multirow{2}{*}{$\begin{array}{l}\text { Operation I } \\
\text { Priority axis }\end{array}$} & \multirow{2}{*}{ 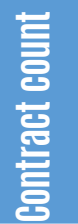 } & \multicolumn{2}{|c|}{ Gontracted Amount } & \multicolumn{2}{|l|}{ Actually paid } \\
\hline & & $\begin{array}{l}\text { Total } \\
\text { [BGN] }\end{array}$ & $\begin{array}{l}\text { ERDF Funding } \\
\text { (BGN) }\end{array}$ & $\begin{array}{l}\text { Total } \\
\text { (BGN) }\end{array}$ & $\begin{array}{l}\text { Actually paid } \\
\text { - ERDF part } \\
\text { (BGN] }\end{array}$ \\
\hline $\begin{array}{l}\text { Operation } 3.1 \text { Enhancement of } \\
\text { Tourism Attractions and Related } \\
\text { Infrastructure }\end{array}$ & 72 & 22264344 & 188081308 & 156122797 & 137118186 \\
\hline $\begin{array}{l}\text { Operation } 3.2 \text { Regional Tourism } \\
\text { Product Development and } \\
\text { Marketing of Destinations }\end{array}$ & 46 & 16446345 & 13978905 & 10547913 & 9437606 \\
\hline $\begin{array}{l}\text { Operation } 3.3 \text { National Tourist } \\
\text { Marketing }\end{array}$ & 14 & 50586770 & 42998754 & 33517978 & 29613674 \\
\hline $\begin{array}{l}\text { Total } \\
\text { Priority axis } 3 \text { Sustainable Tourism } \\
\text { Development }\end{array}$ & 132 & 288297459 & 245058967 & 200188688 & 176169466 \\
\hline
\end{tabular}

Iable 1.: Implementation of priority axis 3 Sustainable Tourism Development of the Operational programme Regional Development 2007-2013, source: http://umispublic. government.bg/ 
Under operation 3.2. the projects are implemented in partnership with at least two municipalities. Eligible activities supporting regional tourism products are divided into six groups:

1. Development of travel packages or diversification of existing ones;

2. Promotional activities - preparation and dissemination of information and promotional materials for the tourist area and offers of support tourism product;

3. Participation in regional, national and international tourism fairs and exhibitions;

4. Studies of the impact of the implemented marketing and advertising;

5. Organizing trips, visits to travel agents, tour operators, travel writers, journalists;

6. Supporting public awareness activities and information services.

Deeper observation of projects shows that there are funded projects related to tourism products with minor potential. In our opinion, this is the result of project selections on the basis of the competition principle among all eligible beneficiaries. Obviously, this leads to a waste of resources and it is inefficient. The accumulated experience clearly indicates that the activities related to tourism should cover the entire territory of the country on the basis of predefined projects. This is reflected in the strategic documents for the programming period 2014 - 2020.

\section{Development of local tourism} potential in the new programming period 2014-2020

According to the final decision on the distribution of the funds within the European Structuring and Investment Funds Bulgaria will have access to a little over 10 billion euro during the programming period 2014-2020. Around 7,57 billion euro are allocated to Cohesion Policy: 3,57 billion euro to the European Regional Development Fund, 2,28 billion euro from the Cohesion Fund, 1,52 billion euro from the European Social Fund, 55,2 million euro are distributed especially for the Initiative for Youth Employment and 165,7 million euro for territorial cooperation. As for the development of food industries and agricultural regions there are 2,34 billion euro allocated from the European Agricultural Fund for Rural Development. The allocated sources from the European Maritime and Fisheries Fund comes up to around 88 million euro. [?]

Successor of Operational programme Regional Development 2007-2013 is Operational programme Regions in Growth (OPRG) 2014-2020, which will be funded from the European Regional Development Fund. [3] The new program will focus on four sectoral policies, one of which is Regional Tourism, delineated in a separate priority axis.

Priority Axis 6 Regional Tourism of OPRG 20142020 provides support for the preservation, promotion and development of cultural and natural heritage of global and regional significance and creation of an entire tourism product for the relevant object. Until 2020, it is expected to provide support to 30 objects which are part of the cultural - historical and natural heritage and have national and world significance as there will be a growth of 1,2 millions in the number of the visits to the supported touristic objects. The indicative budget of the priority axis is $6,53 \%$ of the financial resources of the programme and is significantly lower in comparison to the budget of priority axis 3 under the Operational programme for Regional Development 2007-2013. Besides, it is important to underline that $50 \%$ of the planned financial resource within the ERDF (85 642499 euro allocated for priority axis 6 of the OPRG 2014-2020) will not be allocated as granted funds but will ensure support by means of different financial instruments. 
The projects to be supported should include one or more of the following indicative eligible activities:

- Development of natural, cultural and historical attractions, including religious sites, of national and global significance by restoration, conservation, exhibition, socialization, equipment, introduction of techniques and programs for interpretation and animation;

- Development of supporting infrastructure in the region of attractions (trails and paths of health, climbing routes, horse riding and biking, picnic areas, signposting, visitor information centers);

- Development of regional products and market information, events and information campaigns;

- Training of staff engaged in the attractions, participation in fairs and exhibitions. The following data support the claim, there is a huge local tourist potential. Bulgaria has registered over 40 thousand monuments of immovable cultural heritage of global, national, regional and local significance, as well as 540 natural landmarks. Nine sites are included in the List of World Heritage Sites of UNESCO. Remarks should be made to the rich natural heritage with over 600 mineral springs, rich biodiversity (including 3 national and 11 natural parks) and 160 monasteries, more than 330 museums and galleries, rich traditions in organizing festivals and holidays, preserved ethnographic heritage, national cuisine and quality wines, etc. There are 142 officially announced resorts in the country, of which 58 are spa resorts, 56 mountain climatic resorts and 28 sea resorts. [4]

It is important to note that unlike OPRD 2007-2013, the new programming period provides for funding a limited number of predetermined cultural and natural attractions of national and global significance and religious sites located throughout the country. The regional development policy will focus on priority projects derived from the total 1400 cultural assets of global and national significance, and 25 natural sites and phenomena with the potential to attract tourists.

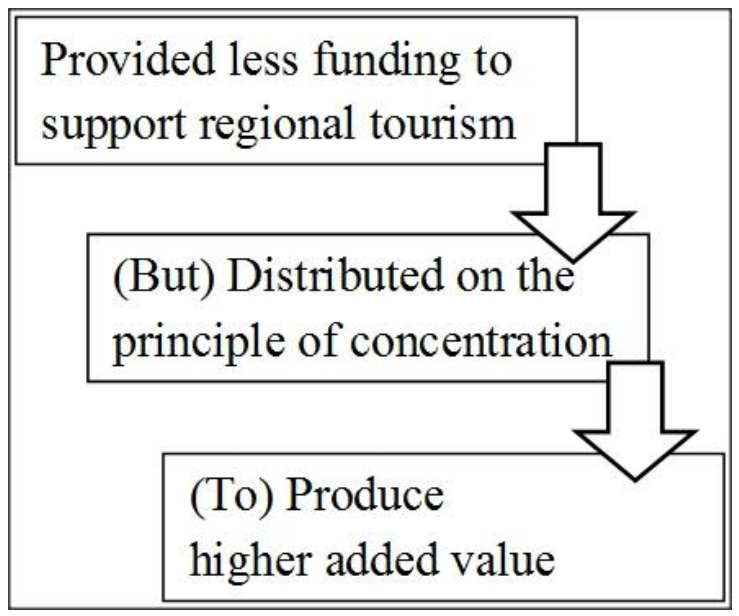

Figure 1: Logic of Priority Axis 6 Regional Tourism of operational programme Regions in Growth 20142020

Here, conclusion can be made that in terms of tourism, OPRG 2014-2020 is based on a new concept. Funding will cover a limited number of predetermined cultural and natural attractions of national and global significance and religious sites with the potential to attract tourist interest located throughout the country, regardless of the differentiation between urban and rural areas. In comparative plan should take into account that the new programming period are provided less funding to support tourism, but in view of their distribution on the principle of concentration is expected to produce higher added value and sustainability (See Figure 1].

From our point of view, despite the growing interest in alternative forms of tourism, the local communities cannot take advantage of their benefits because of some major barriers, such as lack of good infrastructure for the provision of 
these types of tourism and lack of quality information in Bulgaria and abroad.

In conclusion it must be observed that upon the successful implementation of the new operational programme in the part of regional tourism, at the end of the current programming period we can expect to overcome the major barriers, resulting in an increase in the share of sustainable types of tourism, development and promotion of new tourist products such as cultural and historical, spa and wellness, eco and rural tourism, religious, congress, adventure, etc.

The investment in regional tourism will also support the development of accompanying economic sectors, including the light and food industries, and transport services in the regions. Thus, the development of sustainable types of tourism will contribute to the full implementation of the local economic potential and will lead to sustainable growth and generation of employment.

\section{The experience of Burgas Municipality}

Burgas Municipality is one of the largest Bulgarian municipalities which actively takes profit of the European funds for the implementation of policies and the development of the local potential. This is determined by the fact that the municipality possesses very well constructed administrative, financial and technical capacity of identification, grant awarding and implementation of the funded projects.

Burgas municipality is a beneficiary of 37 projects funded by operational programmes at the total amount of 424,7 million BGN (see table 2) within the programming period 2007-2013.

Almost half of the projects of Burgas municipality are co-funded by the European fund for regional development. All of them represent investment projects and their total amount comes up to 224 million BGN. The revised projects which are co-funded by the European fund for regional development, can be divided into 4 groups depending on the object of intervention:

- projects with social character cimprovement of the conditions in the social houses, schools, kinder gardens, healthcare infrastructure);

- projects for the rehabilitation and reconstruction of transport and engineeringtechnical infrastructure;

- projects for the wellbeing construction and renovation of green zones, places for recreation and sport;

- projects for the reconstruction and modernization of cultural infrastructure and objects of the cultural-historical heritage.

All projects have direct or indirect attitude to the development of the local touristic potential. Through the improvement of the social, physical environment and the belonging infrastructure, optimization of the transport system and ensurement of accessible public transport there is an impact on some of the main local resources (human, natural, infrastructure) which are a precondition to the sustainable development of the municipality and increase of its attractiveness and competitivity. 


\begin{tabular}{|c|c|c|c|c|}
\hline $\begin{array}{l}\text { Fund/ Operational } \\
\text { Programme }\end{array}$ & $\begin{array}{l}\text { Number of } \\
\text { contracts }\end{array}$ & $\begin{array}{l}\text { Total amount of the } \\
\text { contracts } \\
\text { [BEN] }\end{array}$ & $\begin{array}{l}\text { Grant } \\
\text { [BGN] }\end{array}$ & $\begin{array}{l}\text { Co-funding by } \\
\text { Burgas } \\
\text { municipality } \\
\text { (BGN] }\end{array}$ \\
\hline \multicolumn{5}{|c|}{ Projects co-funded by the Cohesion fund through: } \\
\hline $\begin{array}{l}\text { Operational programme } \\
\text { Environment }\end{array}$ & 9 & 197316733,82 & 191798767,28 & 6429990,87 \\
\hline \multicolumn{5}{|c|}{ Projects co-funded by the European fund for regional development through: } \\
\hline $\begin{array}{l}\text { Operational programme } \\
\text { Regional Development }\end{array}$ & 14 & 182135038,26 & 143521062,37 & 24544384,91 \\
\hline $\begin{array}{l}\text { Operational programme } \\
\text { Environment }\end{array}$ & 1 & 41408214,36 & 38723561,74 & 2684652,62 \\
\hline $\begin{array}{l}\text { Operational programme } \\
\text { Technical Support }\end{array}$ & 1 & 669619,25 & 669619,25 & 0,00 \\
\hline \multicolumn{5}{|c|}{ Projects co-funded by the European social fund through: } \\
\hline $\begin{array}{l}\text { Operational programme } \\
\text { Human Resources } \\
\text { Development }\end{array}$ & 6 & 2080824,40 & 2080824,40 & 0,00 \\
\hline $\begin{array}{l}\text { Operational programme } \\
\text { Administrative Capacity }\end{array}$ & 6 & 1119838,49 & 1119838,49 & 0,00 \\
\hline Total & 37 projects & 424730268,58 & 377913673,53 & 33659028,40 \\
\hline
\end{tabular}

Table 2: Projects under the operational programmes for the programming period 2007-2013 of Burgas Municipality, Source: http://umispublic. government.bg/

The projects co-funded by the ERDF directly connected with the development of the local touristic potential are three, as one of them, distinguished, is about the restoration and adaptation of the cultural-historical heritage of the island St. Anastasia. The total amount of the grant agreement is a little over 5 million BGN as the intensity of grant is 95\%. The island is a final point of the touristic itinerary which starts from the St. St. Cyril and Methodius Square, passing alongside some museums, the sea garden and the sea bridge from where the sea attraction starts. Only within 3 months after the inauguration, the touristic attractions hosted over then 25000 visitors. As an effect of the implementation of the project is reported the recognition of St. Anastasia as a touristic destination at regional and national scale as the achievement of diversification of the offered products and services in Burgas.
As it is evident from the strategic documents for development of Burgas municipality during the programming period 2014-2020, in the direction of tourism it is planned to develop alternative forms such as cultural, eco and spa tourism. [6,7] This is possible thanks to the availability of rich cultural lifestyle with long-lasting traditions and rich cultural-historical heritage, a wide range of archaeological monuments from the Antiquity, Medieval and the Renaissance. The Geographical situation, the natural dispositions and rich biological diversity is an important factor for the development of the eco tourism in Burgas municipality. Over $43 \%$ of the territory of the Municipality is included in the ecological network Natura 2000. Besides, in the territory of the municipality there are three fields of mineral water, as from the Atanasovsko lake it is extraced mud and lye. 
During the programming period 2014-2020, Burgas municipality elaborates its strategic tourism potential through the development of different type touristic attractions, as a priority the focus will be deployed in the following directions:

- $\quad$ On the basis of the natural dispositions and resources, development of spa resort "Burgas mineral baths" and creation of a new spa destination at Atanasovska kosa;

- $\quad$ Building the touristic attraction "Aqua Kalide-Thermopolis" - archaelogical estate cultural monument with surface of 36 decares where it is located an ancient city with famous thermes visited by the emperors Yustinian the Great, Knstantin Pogonat, sultan Suleiman the Great;

- Building touristic infrastructure of the natural sights - protected natural reserves, lakes, flaura, fauna;

- $\quad$ Restoration and rebuilding of objects of the cultural infrastructure (Planetarium, Oceanarium, Underground touristic attraction, Museum of modern art], enlargement of the exposition surfaces and carrying out events and initiatives in the frame of the cultural calendar of the municipality, as well as encouragement of new initiatives beyond the active summer season;

- Creation of an integrated touristic product on the basis of the traditional local occupations, related to fishery and fishery crafts. In addition to this, there will be put an accent on building accessible and harmonious physical environment; it is planned to carry out interventions for wellbeing construction of green surfaces, squares, pedestrian zones [spaces], wellbeing construction of zones for the large public use, playgrounds and others.

The financially planned projects by Burgas municipality for the programming period 2014-2020 will be carried out through different sources -
European structuring and investment funds, other European and national programmes, own sources at disposal of the municipality, financial instruments , public - private partnership. The larger part of the projects related to the development of the local touristic potential will be carried out in the frame of the OPRG 2014-2020, i.e. they will be co-funded by the European Regional Development Fund.

\section{Conclusion}

Undoubtedly, diversification of the tourism product through the development of alternative forms of tourism leads to the minimization of the seasonal pressure of the mass tourism (sea and winter tourism) and to an adequate exploitation of the unused opportunities for the development of the eco, spa, cultural tourism and so forth. In this way, at a max. degree the local touristic potential is implemented.

Besides, the projects which have direct attitude to the development of new touristic attractions of different type should be carried out isolated, but obligatory in parallel with the projects for the improvement of the physical environment. This is necessary on the one hand, in order to increase the attractiveness of the territory, and on the other hand, these projects contribute to the development of alternative forms of tourism.

The ensuring funding of these projects is a key question for their implementation. In addition to the opportunities, which provides the European Regional Development Fund through the Operational programme Regions in growth 20142020 it is necessary to look actively and use other sources of funding, as grants as well as existing financial instruments for low interest crediting. 


\section{References}

[1] Operational Programme for Regional Development 2007 - 2013, Available from: http://eufunds.bg/bg/page/8, Accessed: 2014-0312

[2] Partnership Agreement of the Republic of Bulgaria Outlining the support from the European Structural and Investment Funds for the 2014-2020 Period, approved by the European Commission on 07th August 2014.

[3] Draft model for the operational Programme Regions in Growth 2014-2020, officially submitted for approval to the European commission on 17th November 2014, Available from: http://eufunds.bg/bg/page/989, Accessed: 201412-30

[4] National Strategy for Regional Development of the Republic of Bulgaria 2012-2022, Available from: http://www.mrrb.government.bg/?controller=cat egory\& catid=72, Accessed: 2014-03-12

[5] National Spatial Development Concept for the period 2013-2025, Available from: http://www.bgregio.eu/media/files/Programiran e\%20\&\%200cenka/ Programirane\%2020142020/NKPR\%\%20proekt.pdf, Accessed: 2014-03-12 [6] Integrated Plan for Urban Restoration and Development of Burgas, Available from: http://ipgvr.bggis.com/Portals/0/docs/2013_12_0 3/IPGVR_Burgas.pdf, Accessed: 2014-12-30

[7] Municipal Plan for Development of Burgas Municipality 2014-2020, Available from: http://www. burgas.bg/bg/info/index/835, Accessed: 2014-12-30 